www.jmscr.igmpublication.org

Impact Factor (SJIF): 6.379

Index Copernicus Value: 71.58

ISSN (e)-2347-176x ISSN (p) 2455-0450

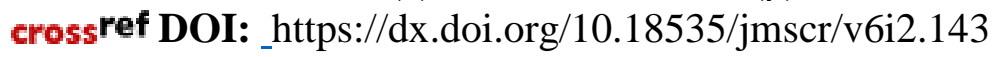

Journal Of Medical Science And Clinical Research

IGM Publication

An Official Publication of IGM Publication

\title{
Effect of Erythropoietin on Fasting Blood Glucose of Diabetic Albino Rats, at 3 Different Doses (EPO 40,100 \& $300 \mathrm{IU} / \mathrm{Kg}$ )
}

\author{
Authors \\ Manju Gari ${ }^{1}$, Vineet Kumar ${ }^{2}$, Lakhan Majhee ${ }^{3}$, Rakhi $\operatorname{Sen}^{4}$, Sabyasachi Mondal ${ }^{5}$, \\ Ravi Ranjan ${ }^{6}$ \\ ${ }^{1}$ Professor and Head of the Dept, Dept. of pharmacology and Therapeutics, RIMS Ranchi \\ ${ }^{2,5,6}$ Junior Resident (A), Dept of Pharmacology and Therapeutics, RIMS Ranchi \\ ${ }^{3}$ Associate Professor, Dept. of Pharmacology and Therapeutics, RIMS Ranchi \\ ${ }^{4}$ Junior Resident (A), Dept of Ophthalmology, NRS MCH, Kolkata \\ Corresponding Author \\ Vineet Kumar
}

Department of Pharmacology, RIMS, Ranchi, India

Mob no 9038582331, Email: kumarvineetcmc@gmail.com

\begin{abstract}
Background: Previously some studies have implicated erythropoietin (EPO) signalling in the regulation of glucose metabolism. Whether EPO can be used treat diabetes and the exact underlying mechanism remain to be elucidated. The present study aimed to investigate whether EPO affects glucose levels, and the underlying mechanisms, in experimental diabetic rats. The effects of EPO $(40,100$ \& $300 \mathrm{IU} / \mathrm{kg}$ three times a week for 4 weeks) on glucose metabolism in streptozotocin, nicotinamide induced diabetic albino rats was studied here.

Methods: 30 albino rats were taken and divided into five groups of six rats in each group. The groups were normal control, diabetic control, diabetic rats treated with EPO in doses of 40,100 and $300 \mathrm{IU} / \mathrm{Kg}$ in the last three groups. Diabetes was induced in four groups by intraperitoneal injection of streptozotocin in the dose of $60 \mathrm{mg} / \mathrm{kg}$. To have an ideal type 2 diabetes model nicotinamide was administered $120 \mathrm{mg} / \mathrm{kg}$ intraperitoneally fifteen minutes before streptozotocin administration. After successful induction of diabetes EPO (40,100 and $300 \mathrm{IU} / \mathrm{kg}$, three times a week) was given to the respective groups for a period of 4 weeks. Fasting blood glucose was estimated on day 0, 7, 14, 21 and 28 of treatment.

Results: In this study EPO showed significant anti-hyperglycaemic effect in all the three groups receiving EPO ( $p<0.05$ in all 3 groups).

Conclusions: From this study we can conclude that EPO has a marked anti-hyperglycaemic effect and the effect is dose dependent. Further studies are required at different doses to establish the optimum dose for its use as an anti-diabetic drug and to alleviate or avoid the adverse effects before it can be used for the treatment of diabetes or its complications.
\end{abstract}

Keywords: EPO (Erythropoietin), Diabetes mellitus (DM), Fasting blood glucose, Streptozotocin.

\section{Introduction}

Diabetes mellitus is a spectrum of common metabolic disorders arising from a variety of pathogenic mechanisms all resulting in hyperglycaemia ${ }^{1}$. The worldwide prevalence of Diabetes mellitus has risen dramatically over the 
past two decades. India had 69.2 million people living with diabetes $(8.7 \%)$ as per the 2015 data. At present India is considered as the Diabetes capital of the World by WHO. World Health Organization (WHO) estimates that India will have 87 million cases of diabetes by $2030^{2}$. A recent estimate suggested that diabetes was the fifth leading cause of death worldwide and was responsible for almost $6.8 \%$ of deaths worldwide 1,3

Fortunately, in many patients complications of diabetes can be mitigated by sustained control of blood glucose level applying wide variety of treatment options. Insulin and oral hypoglycaemic agents are still the major players in the management of the disease. However, complete cure of the disease has been eluding physicians for centuries and the quest for the development of more effective antidiabetic agents is pursued relentlessly.

Erythropoietin (EPO) is best known for its role in promoting red blood cell formation and survival (Krantz, 1991; Lacombe and Mayeux, 1998). Interestingly, recent studies have shown the EPO$\mathrm{R}$ to be present in non-erythroid tissues, including the brain (Digicaylioglu et al.1995), heart (Depping et al., 2005), small bowel (Juul et al., 1999), uterus (Yasuda et al., 1998), kidney (Westenfelder et al., 1999), and pancreatic islets (Fenjves et al., 2003). Accordingly, the biological effects of EPO in non-erythroid tissues are currently being investigated. In particular, several studies have shown the efficacy of EPO in providing cytoprotection in experimental models of tissue injury (for review see Brines and Cerami, 2006).

Several lines of evidence implicate the potential cytoprotective role of EPO in mediating protection from diabetes.

(a) EPO-R (Erythropoietin receptor) is present in human and rodent pancreatic islets (Fenjves et al., 2003). Furthermore, EPO overexpression in human islets has been shown to prevent cytokine-induced cell death (Fenjves et al., 2004). (b) EPO deficiency and a higher incidence of anaemia have been shown in individuals with diabetes, suggesting potential beneficial effects of EPO in the setting of diabetes (Craig et al., 2005; McGill and Bell, 2006; Thomas, 2006).

(c) In a recent major clinical trial involving individuals without diabetes with chronic renal failure, EPO treatment was associated with a significant increase in the incidence of hypoglycaemia as an adverse effect, which raises the intriguing possibility of a direct effect of EPO on pancreatic cells (Drueke et al., 2006).

(d) EPO-R belongs to the cytokine class I receptor superfamily and utilizes a similar signal transduction pathway as the receptors for growth hormone and prolactin, knockouts of which show defects in cell mass and function (Freemark et al., 2002; Liu et al., 2004). Collectively, these data raise the possibility that EPO signalling may have significant biological effects on cells and thus may be relevant to diabetes.

(e) More recently, some new findings indicate that EPO may act as a novel regulator of energy homeostasis. For example, the mice with Epo$\mathrm{R}$ restricted in erythroid system exhibited significant increase in body weight gain due to increased fat mass and a decrease in total activity and energy expenditure compared with Wild type (WT) mice ${ }^{5}$.

The loss of Epo-R in adipocytes negatively regulates mitochondrial function of adipocytes and leads to obese mice with decreased energy expenditure ${ }^{4}$.

In contrast, EPO administration in wild type mice protects the mice from high fat induced obesity and improves glucose intolerance and insulin resistance ${ }^{5}$.

Presently there is a lot of interest in searching for a drug which can increase the beta cell mass for treatment of diabetes. Erythropoietin appears to have a very significant effect on beta cell levels preventing its destruction and also expanding it, 
which no other established anti-diabetic drug is doing till now.

With all the available references erythropoietin was selected as my research topic to evaluate its anti-hyperglycaemic effect with the hope to analyse whether it can be an useful therapy in future for prevention of onset of diabetes/ delay onset of diabetes and decrease insulin resistance.

\section{Materials and Methods}

The study was carried out in the Department of Pharmacology and Therapeutics, Rajendra Institute of Medical Sciences, Ranchi, Jharkhand, India. The whole experiment was conducted in accordance with ethical norms approved by Institutional Animal Ethics Committee (IAEC), Ranchi, Jharkhand, India. Healthy male Wister rats weighing between 150-250 gms were selected. The animals were kept in clean and dry cages with 12:12 hour's light-dark cycle at room temperature and humidity. They were allowed to acclimatize to the available housing condition for 2 weeks before the initiation of experiment and were fed with standard laboratory diets and water ad libitum.

\section{Selection criteria for animals}

- All the animals used for the study were healthy and active in their cage.

- Animals were male wistar rats.

- Weight of the animals used was 150-250 grams.

- Fasting blood sugar before the initiation of study within the range of $200-250 \mathrm{mg} / \mathrm{dl}$.

\section{Drugs used}

- Inj. Erythropoietin (Eporise- 4000, Zuventus Healthcare Ltd.) Batch no. 061516S11

- Streptozotocin (STZ) - \{Streptozotocin Sterile Powder Streptozotocin extrapure, Sisco Research lab. Pvt ltd Batch no. 2582459

- Nicotinamide, 100 gram powder, ANIMED, Kolkata.

\section{Induction of diabetes}

Diabetes was induced by single intraperitoneal injection nicotinamide $(120 / \mathrm{kg})$ followed by injection of freshly prepared streptozotocin $(60 \mathrm{mg} / \mathrm{kg})$ after 15 minutes. Nicotinamide prevents complete destruction of pancreatic beta cells by streptozotocin and thereby produces condition similar to Type 2 DM. $^{6}$

Following 72 hrs of induction, diabetes was confirmed by measuring the fasting blood glucose (FBG) level. The rats having FBG levels between $250-300 \mathrm{mg} / \mathrm{dl}$ were selected for this study.

\section{Group allocation and drug treatment (Table no. 1)}

Study animals were divided into five groups with six animals in each group. One group consisted of non-diabetic rats and other four groups had hyperglycaemic rats with fasting blood glucose 200-250 mg/dl before the start of the experiment. In the four diabetic groups the rats were randomly distributed. Rats were given different treatment according to their groups, once daily for 28 days in the morning at 09:30-10:30 am.

\section{Estimation of fasting blood glucose}

For estimation of FBG rats were kept overnight fasting with free access to water and measured before the induction of diabetes as well as on day $0,7 \mathrm{th}, 14 \mathrm{th}, 21 \mathrm{st}$,and 28th of the study. Blood samples were collected from the tail vein of rats and FBG was measured with the help of Glucometer (Contour TS - Bayer India).

\section{Statistical analysis}

Data entry was done on MS Excel and "SPSS version 20" software was used for data analysis. All the data were expressed as mean $\pm \mathrm{SD}$ and were analysed by using one way ANOVA followed by Post hoc analysis using Tukey's HSD (honestly significant difference) test. $\mathrm{P}$ value $<0.05$ was considered statistically significant.

\section{Results}

Table no 2 shows the mean and standard deviation of fasting blood glucose in all groups from day "0" - day " 28 ". 
Table no. 3 shows the comparison of mean difference between group A (Non diabetic control) and all other groups receiving Erythropoietin throughout the study. Our results shows that throughout the study there was a significant difference between the non-diabetic control and the three groups receiving EPO ( $p$ value $<0.001$ in all the cases). However the mean difference between GROUP A (NORMAL CONTROL) and all the 3 groups receiving EPO, kept on decreasing throughout the study with the decrease being dose dependent. The group receiving highest dose of EPO (300 IU/Kg) showed maximum decrease in blood glucose values while group receiving EPO (40 IU/Kg) showed the minimum decrease.

Table 4 and FIG. 1 shows the comparison of mean difference between group B (Diabetic control) and all other groups receiving Erythropoietin throughout the study. Our results show that throughout the study there was an increase in the difference between the diabetic control and the groups receiving EPO. The increase was maximum in GROUP E and minimum in GROUP C. In group $\mathrm{C}$ the difference became significant from day 14 onwards whereas GROUPS D \& E started showing significant difference from day 7 onwards.

Table 1: Grouping and dosages

\begin{tabular}{|l|c|c|}
\hline Groups & \multicolumn{1}{c|}{ Drug used } & \multicolumn{1}{c|}{ Rat doses } \\
\hline A-Normal Control & $0.1 \mathrm{ml}$ saline solution & $\mathrm{S} / \mathrm{C}$, three times weekly on alternating days \\
\hline B-Diabetic Control & $0.1 \mathrm{ml}$ saline solution & $\mathrm{S} / \mathrm{C}$, three times weekly on alternating days \\
\hline \multicolumn{1}{|c}{ C-Diabetic $($ EPO) } & EPO $(40 \mathrm{U} / \mathrm{kg} \mathrm{bw})$ & $\mathrm{S} / \mathrm{C}$, three times weekly on alternating days \\
\hline D- Diabetic $($ EPO) & EPO $(100 \mathrm{U} / \mathrm{kg} \mathrm{bw})$ & $\mathrm{S} / \mathrm{C}$, three times weekly on alternating days \\
\hline E- Diabetic $($ EPO) & EPO $(300 \mathrm{U} / \mathrm{kg} \mathrm{bw})$ & $\mathrm{S} / \mathrm{C}$, three times weekly on alternating days \\
\hline
\end{tabular}

Table 2: Mean and standard deviations of fasting blood glucose in different groups from day ' 0 ' to day ' 28 '

\begin{tabular}{|l|c|c|c|c|c|}
\hline \multirow{4}{*}{$\begin{array}{l}\text { Fasting } \\
\text { Blood } \\
\text { Glucose }\end{array}$} & $\begin{array}{c}\text { NORMAL } \\
\text { CONTROL } \\
\text { (Group A) }\end{array}$ & $\begin{array}{c}\text { DIABETIC } \\
\text { CONTROL } \\
\text { (Group B) }\end{array}$ & $\begin{array}{c}\text { DIABETIC WITH } \\
\text { EPO (40 U/kg bw) } \\
\text { (Group C) }\end{array}$ & $\begin{array}{c}\text { WITH EPO (100 } \\
\text { U/kg bw) } \\
\text { (Group D) }\end{array}$ & $\begin{array}{c}\text { WITH EPO (300 } \\
\text { U/kg bw) } \\
\text { (Group E) }\end{array}$ \\
\cline { 2 - 7 } & Mean \pm SD & Mean \pm SD & Mean \pm SD & Mean \pm SD & Mean \pm SD \\
\hline Day 0 & $88.17 \pm 2.317$ & $213.67 \pm 10.690$ & $220.83 \pm 14.483$ & $216.33 \pm 11.343$ & $223.17 \pm 13.674$ \\
\hline Day 7 & $86.67 \pm 3.777$ & $223.00 \pm 12.149$ & $206.00 \pm 13.755$ & $199.17 \pm 13.106$ & $191.33 \pm 14.292$ \\
\hline Day 14 & $86.00 \pm 4.243$ & $228.17 \pm 11.250$ & $193.50 \pm 12.292$ & $186.67 \pm 9.750$ & $171.67 \pm 12.242$ \\
\hline Day 21 & $86.83 \pm 3.061$ & $232.67 \pm 11.501$ & $186.17 \pm 10.666$ & $175.67 \pm 9.647$ & $159.00 \pm 11.045$ \\
\hline Day 28 & $87.50 \pm 3.987$ & $237.17 \pm 11.071$ & $183.00 \pm 9.033$ & $171.17 \pm 8.681$ & $150.00 \pm 9.381$ \\
\hline
\end{tabular}

Table 3 Comparison of mean difference between group A (Non diabetic control) and all other groups receiving Erythropoietin throughout the study

\begin{tabular}{|c|c|c|c|c|}
\hline \multirow{2}{*}{\multicolumn{2}{|c|}{$\begin{array}{l}\text { FASTING } \\
\text { GLUCOSE }\end{array}$}} & \multicolumn{3}{|c|}{ NORMAL CONTROL(Group A) } \\
\hline & & \multirow{2}{*}{$\begin{array}{c}\begin{array}{c}\text { DIABETIC WITH EPO } \\
\text { (40 U/kg bw) } \\
\text { (Group C) }\end{array} \\
-132.67\end{array}$} & \multirow{2}{*}{$\begin{array}{c}\text { DIABETIC } \\
\text { WITH EPO }(100 \mathrm{U} / \mathrm{kg} \mathrm{bw}) \\
\text { (Group D) }\end{array}$} & \multirow{2}{*}{$\begin{array}{c}\text { DIABETIC } \\
\text { WITH EPO (300 U/kg bw) } \\
\text { (Group E) } \\
-135 \\
\end{array}$} \\
\hline D & Mean Difference & & & \\
\hline Day 0 & p value & $<0.001$ & $<0.001$ & $<0.001$ \\
\hline \multirow{2}{*}{ Day 7} & Mean Difference & -119.33 & -112.50 & -104.67 \\
\hline & p value & $<0.001$ & $<0.001$ & $<0.001$ \\
\hline \multirow{2}{*}{ Day 14} & Mean Difference & -107.50 & -100.67 & -85.67 \\
\hline & p value & $<0.001$ & $<0.001$ & $<0.001$ \\
\hline \multirow{2}{*}{ Day 21} & Mean Difference & -99.33 & -88.83 & -72.17 \\
\hline & p value & $<0.001$ & $<0.001$ & $<0.001$ \\
\hline \multirow{2}{*}{ Day 28} & Mean Difference & -95.50 & -83.67 & -62.50 \\
\hline & p value & $<0.001$ & $<0.001$ & $<0.001$ \\
\hline
\end{tabular}


Table 4 Comparison of mean difference between group B (Diabetic control) and all other groups receiving Erythropoietin throughout the study.

\begin{tabular}{|l|l|c|c|c|}
\hline \multirow{2}{*}{ FASTING BLOOD GLUCOSE } & \multicolumn{3}{|c|}{ DIABETIC CONTROL (GROUP B) } \\
\cline { 3 - 5 } & $\begin{array}{c}\text { DIABETIC WITH EPO (40 U/kg } \\
\text { bw) } \\
\text { (Group C) }\end{array}$ & $\begin{array}{c}\text { DIABETIC } \\
\text { WITH EPO (100 U/kg } \\
\text { bw) } \\
\text { (Group D) }\end{array}$ & $\begin{array}{c}\text { DITH EPO (300 U/kg } \\
\text { bw) } \\
\text { (Group E) }\end{array}$ \\
\hline \multirow{2}{*}{ Day 0 } & Mean Difference & -7.17 & -2.67 & -9.5 \\
\cline { 2 - 5 } & p value & 0.808 & 0.994 & 0.603 \\
\hline \multirow{2}{*}{ Day 7 } & Mean Difference & 17.000 & 23.83 & 31.67 \\
\cline { 2 - 5 } & p value & 0.137 & 0.017 & 0.001 \\
\hline \multirow{2}{*}{ Day 14 } & Mean Difference & 34.67 & 41.50 & 56.50 \\
\cline { 2 - 5 } & p value & $<0.001$ & $<0.001$ & $<0.001$ \\
\hline \multirow{2}{*}{ Day 21 } & Mean Difference & 46.50 & 57.00 & 73.67 \\
\cline { 2 - 5 } & p value & $<0.001$ & $<0.001$ & $<0.001$ \\
\hline \multirow{2}{*}{ Day 28 } & Mean Difference & 54.17 & 66.00 & $<7.17$ \\
\cline { 2 - 5 } & p value & $<0.001$ & $<0.001$ & $<0.001$ \\
\hline
\end{tabular}

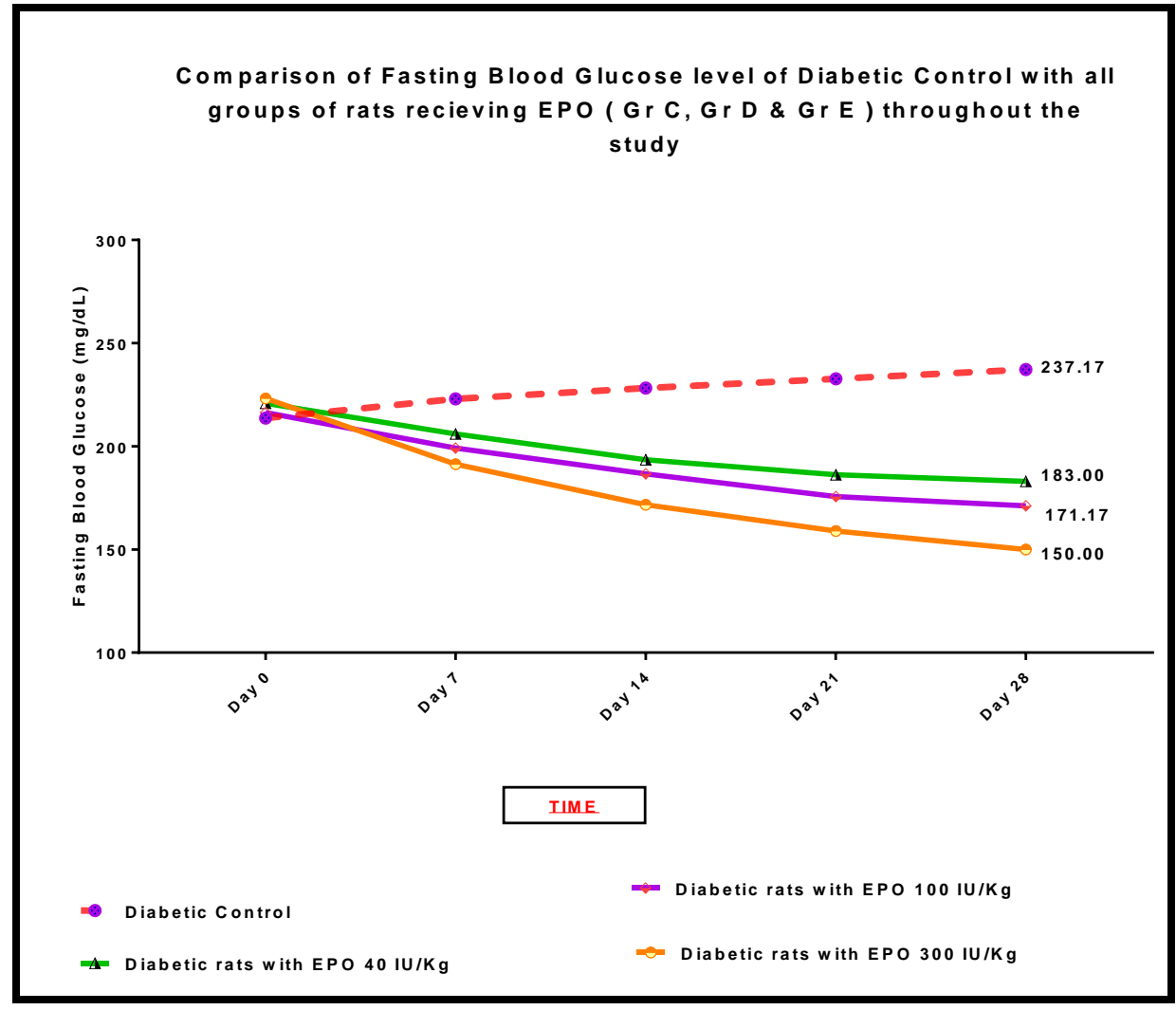

Figure 1

\section{Discussion}

Central to both type 1 and type 2 diabetes is a pancreatic $\beta$-cell defect, which is manifested by $\beta$ -cell death and dysfunction, resulting in hyperglycaemia. rHuEPO (recombinant human erythropoietin) has been previously shown to have cytoprotective effects in non-erythroid tissues (for review see Brines and Cerami, 2006) therefore, this study was carried out to see whether the cytoprotective effects of EPO extended to the pancreatic $\beta$ cells in diabetic animal models.

The current study shows that EPO causes decrease in the plasma glucose of diabetic rats in a dose dependant manner with the higher dose of EPO causing a higher decrease of plasma glucose. However even the highest dose used in this study 
(EPO- $300 \mathrm{IU} / \mathrm{Kg}$ ) couldn't decrease the blood glucose to normo-glycaemic levels.

The results of our study are similar to the study done by Choi D, Woo M, et $\mathrm{al}^{7}$ who found that EPO caused decrease in blood glucose in mice and the values remained consistently low throughout the study. They also found that EPO provided cytoprotection through angiogenesis.

Ho-Shan $\mathrm{Niu}^{8}$ et al too had obtained similar results to our study with EPO in dose of 100 $\mathrm{IU} / \mathrm{Kg}$ where there was significant decrease of blood glucose in all the STZ induced rats receiving EPO. It also increased the insulin sensitivity. They found that the decrease in the GLUT4 level in skeletal muscle was reversed by EPO, and the increase in the hepatic enzyme phosphoenolpyruvate carboxykinase (PEPCK) expression in liver was reduced by EPO, as shown in $\mathrm{STZ}$ rats $[\mathrm{EPO}=0.5 \mathrm{mg} / \mathrm{kg} / \mathrm{day}$ ].

Chen $\mathrm{LN}^{9}$ et al had findings similar to our research that $(300 \mathrm{U} / \mathrm{kg}$ three times a week for 4 weeks) EPO significantly decreased the fasting blood glucose, the area under the curve of the oral glucose tolerance and insulin tolerance tests and Lalanine gluconeogenesis. Ultrastructural examination of the pancreatic islets revealed that EPO prevented dysfunction of pancreatic $\beta$-cells in experimental diabetic rats and increased the activities of superoxide dismutase and glutathione peroxidase, and decreased the level of malondialdehyde, indicating that EPO modulated glucose metabolism and improved pancreatic $\beta$ - cells damage by increasing anti-oxidation.

Katz O, Neumann D et al ${ }^{10}$ found in their research in 2010 that $\mathrm{HbA} 1 \mathrm{c}$ was reduced by $18 \%$ and $15 \%$ in tg6 mice and rHuEPO treated ob/ob mice respectively, compared to their relevant control groups during the third week of rHuEPO treatment. They also found that rHuEPO treated $o b / o b$ mice gained less weight compared to the non-treated $o b / o b$ mice. Hence, while non-treated $o b / o b$ mice had $24 \%$ weight gain, the rHuEPO treated $o b / o b$ mice had only $17 \%$ weight gain $(P<0.004)$, in spite of the fact that there was no difference in food intake between these groups.
Desouki N.I.E et al ${ }^{11}$ too had similar findings with EPO $40 \mathrm{IU} / \mathrm{Kg}$ in diabetic rats. Treatment with EPO (40 U/kg bw) three times weekly on alternating days, for 3 weeks significantly reduced the plasma glucose levels. It also significantly increased the plasma insulin levels as compared to normal control. On the other hand, the non-treated diabetic control rats showed a significant decrease in the insulin levels as compared to the normal control rats.

The anti-hyperglycaemic effect of EPO might be due to the following mechanisms:

a) It appears that the protective effect of rHuEPO on the $\beta$ cells under diabetes conditions occurs largely through the promotion of $\beta$-cell growth and survival rather than through direct effects on $\beta$-cell function. ${ }^{7,9}$

b) There is a subsequent increase in plasma insulin level following introduction of EPO therapy in diabetic rats. ${ }^{11}$

c) EPO has also been shown to provide cytoprotection through angiogenesis. To assess the vasculature, they examined for the presence of factor VIII and CD31, both endothelial cell markers which were present in higher concentrations within the islets of mice in the rHuEPO-treated group compared with saline-injected controls. $^{7}$

d) Expression of c-myc, a STAT target gene which has potent proliferative effects, was increased in isolated islets in response to systemic rHuEPO treatment. They also found an increase in mRNA transcript levels of c-kit in the isolated islets of rHuEPO treated mice. C-kit is a well-known stem cell marker that is present in regenerating pancreatic beta cells after islet destruction (Tiemann et al., 2007). These findings suggest that rHuEPO may promote anti-apoptotic and proliferative effects on beta cells through these target genes. $^{7}$

e) The decrease in the GLUT4 level in skeletal muscle was reversed by EPO, and the increase in the hepatic enzyme 
phosphoenolpyruvate carboxykinase (PEPCK) expression in liver was reduced by EPO, as shown in STZ rats $[\mathrm{EPO}=0.5 \mathrm{mg} / \mathrm{kg} / \mathrm{day}] .^{8}$

Thus we see that EPO has a very significant effect on blood glucose levels and acts by directly increasing the $\beta$ cell mass and preventing its further destruction by various mechanisms at the cellular and gene level, which no other antidiabetic agent can do till now. Hence when used as an antidiabetic agent it can better prevent the diabetic complications than any other antidiabetic agents being used presently.

However the dose at which its full antidiabetic action would be present will be much higher than the dose being used for its hematopoietic effect. Thus we need to be careful about its main adverse effects of thrombo-embolic events due to hyperviscosity and probably cause an increase in tumour growth too. ${ }^{12}$

To prevent the adverse effects we can use the nonerythropoietic analogue of erythropoietin which is currently under research and is yielding promising results in diabetes similar to erythropoietin but not causing any increase in the RBCs level or total Hb. concentration. ${ }^{13,14,15}$

\section{Conclusion}

The present study concludes that EPO causes a decrease in blood glucose in in a dose depended manner when given to diabetic rats. Further studies with a larger sample size and longer duration and using higher doses of EPO, will further validate the results and prove the effectiveness of EPO in management of diabetes in long term.

Financial Support and Sponsorship: Nil.

Conflicts of Interest: There are no conflicts of interest.

\section{References}

1. Alvin C Powers. Diabetes Mellitus: Diagnosis, Classification and Pathophysiology. Harrison's principles of internal medicine. $19^{\text {th }}$ edition.

2015;417:23992407.

2. Shaw JE, Sicree RA, Zimmet PZ. Global estimates of the prevalence of diabetes for 2010 and 2030. Diabetes Res ClinPract 2010;87:4-14.

3. Wild S, Roglic G, Green A, Sicree R, King H. Global prevalence of diabetes: Estimates for the year 2000 and projections for 2030. Diabetes Care 2004;27:1047-53.

4. Obara, N., Suzuki, N., Kim, K., Nagasawa, T., Imagawa, S., Yamamoto, M., 2008. Repression via the GATA box is essential for tissue-specific erythropoietin gene expression. Blood 111, 5223-5232.

5. E. S. Fenjves, M. S. Ochoa, O. Cabrera, A. J. Mendez, N. S. Kenyon, L. Inverardi, and C. Ricordi, "Human, nonhuman primate, and rat pancreatic islets express erythropoietin receptors.," Transplantation vol. 75, no. 8, pp. 1356-60, Apr. 2003.

6. Masiello P, Broca C, Gross R, Roye M, Manteghetti M, Hillaire-Buys D, et al. Experimental NIDDM: development of a new model in adult rats administered streptozotocin and nicotinamide.Diabetes. 1998 Feb 1;47(2):224-9.

7. Choi D, Woo M, et al Erythropoietin protects against diabetes through direct effects on pancreatic cells. J. Exp. Med. Vol. 207 No. 13 2831-2842

8. Niu HS. Erythropoietin ameliorates hyperglycemia in type 1-like diabetic rats. Drug Design, Development and Therapy 2016:10 1877-1884.

9. Chen LN. Erythropoietin improves glucose metabolism and pancreatic $\beta$-cell damage in experimental diabetic rats. Molecular medicine $\quad 2015$. https://doi.org/10.3892/mmr.2015.4006

10. Katz O, Neumann D et al. Erythropoietin treatment leads to reduced blood glucose levels and body mass: insights from 
murine models. Journal of Endocrinology. April 1, 2010205 87-95

11. Desouki N.I.E et al. Improvement in betaislets of Langerhans in alloxan-induced diabetic rats by erythropoietin and spirulina. The Journal of Basic \& Applied Zoology (2015) 71, 20-31

12. Jelkmann K. Physiology and Pharmacology of Erythropoietin. Transfusion Medicine Hemotherapy 2013;40:302-309

13. Watanabe M. A Non Haematopoietic Erythropoietin Analogue, ARA 290, Inhibits Macrophage Activation and Prevents the Transplanted Islet Graft Damage. Am J Transplant. 2015; 15 (suppl 3).

14. Nakamura M, Nagafuchi S, Yamaguchi K, TakakiR. :The role of thymic immunity and insulitis in the development of streptozocin-induced diabetes in mice. Diabetes. 1984 Sep;33(9):894-900. Bell $\mathrm{RC}$,

15. Collino $\mathrm{M}$ et al. A non-erythropoietic peptide derivative of erythropoietin decreases susceptibility to diet-induced insulin resistance in mice. British Journal of Pharmacology (2014) 171 5802-5815. 